DRAFT - PLEASE CITE PUBLISHED VERSION: DOI: 10.5840/soctheorpract2017103019

Social Theory and Practice Volume 43, Issue 4, October 2017: 691-716.

\title{
Resolving the Dilemma of Democratic Informal Politics
}

\author{
Seth Mayer
}

\begin{abstract}
The way citizens regard and treat one another in everyday life, even when they are not engaged in straightforwardly "political" activities, matters for achieving democratic ideals. This claim provokes an underexamined unease in many. Here I articulate these concerns, which I argue are prompted by the approaches most often associated with these issues. Such theories, like democratic communitarianism, require problematic sorts of unity in everyday social life. To avoid these difficulties, I offer an alternative, called procedural democratic informal politics, which allows democrats to evaluate everyday life without demanding questionable forms of unity within it.
\end{abstract}

Key Words: Democracy, Informal Politics, Everyday Life, Proceduralism, Democratic Communitarianism

The way citizens regard and treat one another in everyday life, even when they are not engaged in straightforwardly "political” activities, matters for achieving democratic ideals. Whether a society holds prejudices against broad segments of the populationviewing them as likely criminals - affects who participates in democratic governance and on what terms. ${ }^{1}$ Whether citizens expect their political conversations to be grounded in truth determines if democratic deliberation is possible. ${ }^{2}$ And whether child-rearing practices are structured one way or another affects which political values children end up committed to. ${ }^{3}$ Such elements of everyday life are deeply shaped by formal legal

\footnotetext{
${ }^{1}$ Lerman and Weaver, Arresting Citizenship, 125-37; Gottschalk, Caught, 247-48.

${ }^{2}$ Stanley, How Propaganda Works, 90-91.

${ }^{3}$ Miklikowska and Hurme, "Democracy Begins at Home." See also Rosenblum, "Democratic Families," which makes clear that although realizing democracy depends upon informal life, informal life should not be expected to resemble the formal institutions of democracy. The informal sphere must be set up to support democracy's realization, but that does not necessarily demand things like democratic decision-making in families, religious institutions, or other nonstate institutions.
} 
institutions, but are not fully determined by them. Yet despite arising in part from the spontaneous order of everyday interactions, the realization of democracy relies upon these subtle elements of social life. Thus, normative democratic theory ought to pay attention to this realm.

Pointing this out provokes an underexamined unease in many. In what follows, I articulate these concerns and put forward an approach — procedural democratic informal politics - that can avoid them. In the process, I introduce several significant distinctions into democratic theory.

I defend a democratic concern for everyday life against those who think that when normatively evaluating social interactions that occur outside of political institutions, we should not take democracy into account. For some critics, the goal of shaping informal interactions to support democracy is inherently illegitimate. Others question the means required to pursue democratic values within civil society. Against them, I advocate the need to think about how to make patterns of informal interaction compatible with democratic government. To do so, I articulate a way to understand everyday life as important for democracy without making implausible demands of it.

This project comes in the wake of Susan Moller Okin and G. A. Cohen's challenges to Rawlsian theories of justice to consider everyday life, Philip Pettit's discussions of cultures of contestation, and Axel Honneth's recent studies of ethical life. ${ }^{4}$ I argue that democracy makes normative demands of the informal sphere- the realm of custom, collective presuppositions, and other decentralized social forces affecting action and understanding. My discussion focuses on a broad conceptual point: given the nature

\footnotetext{
${ }^{4}$ Okin, Justice, Gender, and the Family; Cohen, Rescuing Justice and Equality; Pettit, On the People's Terms; Honneth, Freedom's Right. Allen's Talking to Strangers also emphasizes the importance of informal interactions for pursuing racial justice.
} 
of democratic ideals, formal institutions alone cannot realize democracy. We need an adequate version of what I will call democratic informal politics, which requires expanding the scope of democratic concern to civil society interactions.

Although democratic communitarians are often associated with such informal political matters, their approach threatens to generate a worrisome dilemma. The means they recommend to achieve democratically required informal conditions-like Rousseau's proposed state supervision of culture-face insuperable objections. We cannot sidestep these issues by focusing only on formal institutions, though; democracy requires particular patterns of action, belief, and commitment in the informal sphere.

Democrats must reckon with the informal sphere's dispersed and decentralized normative structures without compromising important values. If we pursue democratic communitarian informal politics, we seem to meet the first horn of our dilemma: objections to the means necessary to achieving this goal. If we give up this goal, we meet the second horn: the failure to achieve democratic ideals.

My alternative procedural approach avoids this dilemma. Unlike democratic communitarianism, my conception of democratic informal politics considers democracy achievable not just in unified cultures, but also fragmentary ones. This procedural conception is satisfied if the informal sphere's elements do not conflict with the democratic process, whether those elements cohere into a unified whole or not. It finds a happy medium between ignoring everyday life and placing problematic demands on it.

\section{Democratic Informal Politics}

\section{A. Introducing the Informalist Thesis}


My aim in this section is to explain and defend the thought that democracy depends on some particular type (or types) of democratic informal politics. I call this claim the informalist thesis. The nature of this dependence may vary, but any plausible conception of democracy causally depends on what the informal sphere is like. I will focus on such causal dependence in my argument: the informal sphere must operate so as to provide an essential causal basis for formal institutions to function democratically. ${ }^{5}$ I do not defend this thesis with respect to a particular conception of democracy, but regarding the general concept of democracy.

To explicate what I mean by the general concept of democracy, I make use of the distinction between concepts and conceptions. As Christine Korsgaard explains, "the concept names the problem, the conception proposes a solution." ${ }^{\prime 6}$ The concept of democracy, as I understand it, names the problem of trying to make political decisions in ways that respect the freedom and equality of adults subject to those decisions. ${ }^{7}$ Different normative democratic theories attempt to articulate what such free and equal standing means. My stipulative definition of democracy spells out what kind of issues and

\footnotetext{
${ }^{5}$ Democracy can depend upon formal politics in a causal or constitutive sense. More demanding conceptions of democracy will require informal politics to embody certain democratic elements as a constituent part of achieving democracy. Other views will acknowledge that the achievement of certain sorts of democratic informal politics are causally necessary for achieving democracy, even if it is not inherently part of that view's democratic ideals. For democratic theories that treat informal politics as a constitutive element of their ideals (i.e. claiming that democracy is itself realized in everyday life, to some extent), the informalist thesis will be trivially true. As a result, I focus on the causal claim here.

Focusing on the claim that democracy causally depends on democratic informal politics does not necessitate denying that formal institutions are central to democratic ideals. Nor does it rule out reciprocal causal dependence of informal politics on formal institutions. On the contrary, such reciprocal causation between the formal and informal is clearly significant for the realization of democracy. Institutional contexts can establish the conditions for the development of democratic informal politics, which in turn can support and maintain the democratic qualities of those formal institutions.

${ }^{6}$ Korsgaard, Sources of Normativity, 114.

${ }^{7}$ I do not mean to suggest that these are the only possible values a political system can or should aim at. These are simply the democratically relevant ones.
} 
problems democracy is meant to address while particular conceptions (political liberal, pluralist, minimalist, etc.) take varying approaches to these problems and issues. As I proceed, I use the concepts of political freedom and equality as placeholders for the various detailed proposals that spell out general interpretations of democracy. My argument applies to all such conceptions.

Although the numerous conceptions of democracy interpret the concept of free and equal standing differently, I argue they all require certain sorts of informal politics. I do not assume minimalist, pluralist, or deliberative, premises, then —any of these genuine sorts of normative democratic theory (and others) remain on the table. Instead, I assume that democracy of some sort is justified and then argue that the informal sphere must meet some sort of democratic requirements. I will not determine what specific sort of requirements democratic informal politics should involve; those specifics must be filled in by one's chosen conception of democracy, which, I have explained, is left open here.

Moreover, my arguments are only meant to address those committed to maintaining a democratic standpoint. Some may reject democracy or simply be comfortable sacrificing normative democratic legitimacy in favor of other ideals, such as economic efficiency, individual negative liberty, or overall social well-being. In this paper, I do not have the space to mount a defense of the priority of democratic legitimacy, so I leave that task to others. ${ }^{8}$

In any democracy, individuals must have the status of a free and equal member with respect to political decision-making; that commitment is internal to the concept.

\footnotetext{
${ }^{8}$ For one argument for prioritizing legitimacy over other values, see Pettit, On the People's Terms.
} 
Noting the relational character of this status is the first step toward vindicating the informalist thesis. This status entails that others must recognize and respect certain claims a citizen might make. Theorists generally agree that political freedom and equality involve things like a citizen's right to vote, to exercise freedom of speech, and to have significant access to the political process. Most also require the rule of law, where laws apply to all citizens equally. These requirements set out the baseline threshold for what it means to protect citizens' free and equal status. ${ }^{9}$

My discussion of the informalist thesis relies on the notion of what G. A. Cohen calls a site: a location, a set of institutions or practices, a being, or an object that one can apply certain standards or norms to. ${ }^{10}$ Applying these standards or norms means interpreting something as having a certain normative structure; it shows up as the sort of thing that can be right or wrong, better or worse. Here I focus on two broad sites, which I will call the formal sphere and the informal sphere.

The formal sphere is the normative order promulgated by the somewhat centralized authority or authorities in a polity—usually the state. This positive, effective authority originates in a particular set of institutions and its claims on people have a general form (applying to broad categories of things). Such institutions claim to give

\footnotetext{
${ }^{9}$ In suggesting that democracy requires certain baseline conditions, I do not mean to deny that a society can be more or less democratic. Nonetheless, we can also identify when there is an adequate level of democracy relative to particular benchmarks. For instance, a democracy may be adequate insofar as its legal system treats citizens in a normatively legitimate way or insofar as it should be understood to speak on behalf of its people in the international arena. Democracies may go beyond such levels of sufficiency, however, in perfectly and completely achieving free and equal status for all. Viewing democratic ideals in either on-off adequacy terms or less-more scalar terms can be useful, depending on what philosophers aim to understand about a democracy. In this paper, I will focus upon adequacy relative to a system's normative democratic legitimacy. Although evaluating whether we have more or less democracy can be useful for various purposes, identifying sufficiency conditions for legitimate democratic decision-making is crucial, as well, and is central to democratic theory.

${ }^{10}$ Cohen, Rescuing Justice and Equality. See also Dryzek, Deliberative Democracy and Beyond.
} 
people reason to conform to patterns that are made more or less explicit in legal rules, standards, and principles. An explicit, socially effective rule is not automatically within the formal sphere; the appropriate political authorities must also recognize it. ${ }^{11}$

The informal sphere involves normative structures with a general form, which make claims on some category of thing. In this respect, they are unlike personal, particularized normative structures between friends - an act or belief that Rolf expects of Stefan, say. ${ }^{12}$ Crucially, the authority governing informal normative structures is anonymous: a sizeable portion of civil society treats an action or belief as subject to certain criteria. Individuals aren't understood to respect informal normative structures due to a state institution or an individual's demands. Instead, normative structures hold sway if substantial portions of society are best interpreted as seeing them as authoritative. The category of informal structures includes collective background beliefs and attitudes, presuppositions, self-understandings, customs, conventions, social expectations, shared practices, and collective ideals. ${ }^{13}$

\footnotetext{
${ }^{11}$ Rules of etiquette, for instance, might be articulated with tedious explicitness by Miss Manners, but are nonetheless not part of the formal sphere. The authority these rules claim does not find its source in any centralized institution. Suppose a group of people got together and formed The Etiquette Committee. They promulgate new regulations of etiquette in a particular society. They make claims of a general form from within their particular institution, i.e. the Committee. That, one might think, seems like enough to push such a committee into the formal sphere. The committee does not yet count as part of the formal sphere, however, insofar as the Committee's authority doesn't hold sway in the society overall. They can make claims, but they have no force; no pattern of conduct or belief corresponds to what the Committee is putting forward. If people started to follow its dictates - whether out of being persuaded or coerced - then the Committee would rightly be considered part of the formal institutional structure. It might rival or complement the state's authority, but insofar as it regulated a community it would be part of the formal sphere and its promulgated rules would count as products of that sphere.

${ }^{12}$ Perhaps Rolf and Stefan have the shared expectation that Rolf will chop the vegetables and Stefan will cook them when they dine together. For my purposes, I leave such cases aside; they do not generally have democratic importance (with possible, rare exceptions).

${ }^{13}$ There is a deeply contested issue that relates to where to place the market in the account I am offering. Neoliberals see the market as something that springs up spontaneously without the aid
} 
We frequently judge whether informal normative structures hold sway in a society. For instance: "In Germany, one makes eye contact while making a toast." This judgment does not require that this custom always be followed or that agents "have it in mind" while acting. Visitors to Germany often fail to observe the practice initially and natives may conform almost automatically. An observer, however, could attest that the custom has authority in Germany. Informal normative structures are sometimes much less explicit, but can nonetheless effectively structure action or belief in social orders, as with implicit bias. Like the formal sphere, the informal sphere is a dynamic system. It includes stable components, those that emerge or fade away, and actors working to conserve or transform the system. ${ }^{14}$

Both the formal and informal spheres feature certain patterns and structures. Some matter for democracy, while others do not. ${ }^{15}$ I call normative structures that matter politically formal or informal politics. ${ }^{16}$ Formal politics involves legislative procedures, voting, and the like. Informal politics is less widely discussed. ${ }^{17}$ Whereas formal politics

of state institutions; it is arrived at as the most efficient way to conduct economic transactions. Their critics, like Karl Polanyi and many others, understand markets to be something made possible by state intervention into social life. See Polanyi, The Great Transformation. Which side is correct will determine whether spheres of market exchange should be understood as mainly in the formal or informal sphere. The former see market exchange as a more informal sort of normative structure, while the latter see it as part of the formal sphere in modern capitalist societies. Some intermediate answer may also be possible, as well, but I do not attempt to resolve these issues here.

${ }^{14}$ There also may be various sub-informal spheres, such as the counter-publics Michael Dawson and Nancy Fraser discuss. See Dawson, Black Visions; Fraser, "Rethinking the Public Sphere."

${ }^{15}$ For instance, whether a political community has collective ideals about space travel or having a national park system need not affect citizens' freedom and equality. The hegemony of homophobic norms, however, matters politically.

${ }^{16}$ To be clear, the content of the informal structures may not be explicitly political (i.e. regulating something with reference to freedom or equality), while still having political significance.

${ }^{17}$ Joshua Cohen says it concerns "the public culture [...] where the stakes include discursive presuppositions, as well as social conventions and norms backed by decentralized sanctions." Cohen, "Privacy, Pluralism, and Democracy," 318. Cohen does not self-consciously attempt to define informal politics in this quote, but he refers to T.M. Scanlon's work in a way that makes 
is tied to the state, informal politics closely relates to civil society, the informal sphere that I have been introducing. The core of my focus will be how this informal domain plays into democratic theory. In focusing on informal politics, I do not deny that democratic formal politics will be the central mechanism for adjudicating social disagreements, only that this adjudication partially relies on informal processes, as well. Within the context of decision-making processes, rights enforcement mechanisms, and other institutional structures, members of society must act in ways that allow decisions to be reached in ways that respect citizens' political freedom and equality. Formal institutions must leave space for —and enable — citizens to develop civil society's norms and understandings in ways that will allow democracy to be maintained.

\section{B. Justifying the Informalist Thesis}

To defend the informalist thesis, I will show that if we want to realize democracy, components of the informal sphere must be structured to be responsive to the values of universal political freedom and equality. That is, democracy demands democratic informal politics. I cannot detail the ways relevant parts of the informal sphere might respect democratic values here. ${ }^{18}$ I simply suggest that democratic values, on whatever interpretation turns out to be correct, require such responsiveness. To be clear, informalists do not require each citizen to adopt some set of democratic commitments. Rather, they care when normative structures in tension with democracy gain effective sway in a significant part of the informal sphere.

clear he is referring to this phrase, which Scanlon coins in that essay. He refers specifically to Scanlon, "The Difficulty of Tolerance."

${ }^{18}$ Broadly, informal normative structures might causally produce or intrinsically constitute democracy's realization. 
To motivate the informalist thesis, I evaluate the opposing view, ultimately shifting the burden onto it. One might claim the formal sphere is all that is necessary for realizing democracy; only this sphere's authoritative normative structures are needed to realize universal freedom and equality in a society's political system. Constituting the state's institutions in the right way results in democracy, the thought goes. Call this claim the formalist thesis. It suggests that democracy will be achieved if citizens are accorded a free and equal status when engaging with the centralized formal institutions of democracy; the scope of democracy's demands extends no further than these structures.

People hold this thesis for various reasons. Some think that, if there are any permissible ways to improve the informal sphere, we should. They worry, though, that this otherwise decent goal, in fact, requires illicit means. The next section of this paper lays out the objections such a holder of the formalist thesis might make and offers replies.

Others hold the formalist thesis due to a principled concern for preserving individuals' spheres of negative freedom; they reject informalist aims. "Private" norms need not involve equal respect or other democratic values, they argue. For them, democracy is consistent with individuals restricting their property discriminatorily (in restrictive covenants or the refusal to rent or sell to certain groups). Such formalists accept that individual exercises of negative liberty may give significant sway to questionable informal normative structures. Their commitment to negative freedom means that they do not aim at any particular sort of informal politics, since they shun attempts to restructure civil society as illegitimate.

When rejecting informalist aims, formalists can either try to maintain their commitment to democracy or give it up. In what follows, I argue that those who reject 
informalist aims can only take the second option and jettison their democratic

commitments. Neglecting the informal sphere means ignoring crucial factors that affect

whether society meets the threshold for democratic legitimacy. Potential counter-

democratic currents in everyday life can undermine citizens' free and equal status relative to the political decision-making process.

While few formalists remain committed to democratic ideals, I initially focus on this position, demonstrating its implausibility in order to bolster the informalist thesis. When formalists deem informalist aims impermissible, they allow the hegemony of informal norms that undermine some citizens' equal political status. ${ }^{19}$ As a result, they cannot remain democrats, unless they give up such formalist stances in favor of informalism.

Rejecting informalist aims starts to look antidemocratic once one considers how individuals' informal statuses can affect their formal political status. ${ }^{20}$ The effective exercise of democratic rights and freedoms depends on the informal sphere's constitution. Informal statuses at least partially determine if people are recognized and respected in the

${ }^{19}$ Pincione and Tesòn's Rational Choice and Democratic Deliberation is an especially radical example of the libertarian adherence to negative freedom as the ultimate value. They attack majoritarian political procedures, favoring minimalist government where people choose to enter small homogenous communities, which may not be liberal and democratic. What they see as very basic rights (contract and right of exit) are enforced by an overarching court system, but they eschew coercive structures beyond that. Animated by a concern for negative freedom, they only leave room for political equality as an instrument of political freedom (i.e. as something discretionary, rather than something political frameworks are obligated to protect). If a view like theirs were committed to formal equality as a necessary instrument for freedom, my arguments provide reasons for thinking that, to provide political equality's fair value, democratic informal politics is also necessary. Pincione and Tesòn make clear that they are happy to dispense with even formal political equality and are, as a result, outside the scope of my discussion here. A view much like theirs might view formal political equality as instrumental, but indispensible: for anyone to enjoy negative freedom they would need a community where they had formal political equality. Such a formalist view is subject to the arguments I lay out here.

${ }^{20}$ The following argument has some parallels with Rawls' recognition that citizens must be accorded the fair value of their rights. See Rawls, A Theory of Justice, section 36. 
formal sphere as co-equals. Class, gender, race, social role, appearance, manner of dress, and a manifold of other things prompt various response patterns, varying across situational context, but maintaining certain core, if plastic, meanings. These constellations have differing degrees of stability and are shapeable by human agency to varying degrees. It's a manifest fact that these social markers matter for everyday life.

Recall that the formalist thesis suggests democracy only makes demands of the formal sphere's normative structures and that the informal sphere need not and ought not be pushed to be responsive to democratic values. It claims realizing democratic norms in the informal sphere entails problematic limits on liberty; patterns in this sphere may be constituted any which way, as a result. No normative constraints on informal life are democratically necessary, on this view; actors in civil society can exercise their rights however they'd like without undermining democracy. This formalist position doesn't deny that formal institutions must legally regulate individuals in order to protect individuals' rights and establish democratic decision-making procedures. The view does, however, object to the further informalist claim that civil society ought to shape itself to be compatible with democracy. Actors in civil society such as individuals, social groups, non-governmental organizations, and political movements need not work to maintain an overall ethos compatible with democracy. Formalists are wary of expecting informal democratic action, such as practicing and promoting social norms that are not rigidly hierarchical or building civic competences through democratic pedagogical approaches. ${ }^{21}$

\footnotetext{
${ }^{21}$ In saying that civil society actors can constrain themselves and shape informal social life for the sake of cultivating a democratic informal sphere, I do not deny that formal institutions play a crucial role in enabling the maintenance of democratic informal politics. Formal institutions support democratic informal politics (by protecting rights, providing resources, and so on), which can, in turn, reciprocally support the functioning of those same democratic institutions.
} 
To see the strangeness of the formalist thesis, one only need consider its concrete implications. When a group is arbitrarily treated unequally in economic life, in social situations, and in personal relationships, their freedom to pursue certain paths in life is, resultantly, restricted. Yet formalism suggests they can still realize their political freedom and equality in the formal sphere, acting (and being treated as) full participants in democracy. Informal normative structures would not causally undermine citizens' freedom and equality in the formal sphere - to enjoy free speech rights, run for office, and so on. Reverberations of status markers in the informal sphere are somehow kept out of the formal one, according to this view. Supposedly, from a democratic perspective, there is a strict causal separation between these two realms.

This strict compartmentalization of the informal and formal spheres strains credulity. For one, people have long pointed out that patterns of privilege (like educational attainment and economic power) can exclude people from enjoying the fair value of their formal rights. ${ }^{22}$ Given how much bias is implicit and unconscious, it would be remarkable if conscious democratic commitment alone could easily overcome it. ${ }^{23}$ Even if biases in the informal sphere were consciously held, why and how would formal norms be constituted democratically? Something must explain how people seen as unworthy of basic social respect and esteem could simultaneously enjoy political freedom and equality, to take an extreme, but sadly realistic example. Without that story, it's hard to accept the formalist thesis. ${ }^{24}$ These points suggest that democratic theory requires

\footnotetext{
${ }^{22}$ See Sanders, "Against Deliberation"; Young, Justice and the Politics of Difference; Young, Inclusion and Democracy.

${ }^{23}$ For discussion of implicit bias, see Fricker, Epistemic Injustice.

${ }^{24} \mathrm{I}$ 'm not making a claim about conceptual possibility here, but about something like empirical probability. In a discussion of more specific theories of democracy (rather than its general
} 
some sort of democratic informal politics as an enabling precondition for achieving democratic ideals to an extent adequate for normatively legitimacy. Defending the opposing formalist thesis will depend to some degree on empirical evidence. ${ }^{25}$ Even without having all such evidence on the table, the formalist thesis must assume the burden of proof. Its empirical claims are hard to take seriously. ${ }^{26}$

Without definitively refuting the formalist thesis, I have suggested that it lacks initial plausibility and attractiveness. Democratic theorists should affirm the informalist thesis, absent very powerful empirical evidence and/or normative arguments against it.

\section{Objections to Democratic Informal Politics}

Democratic communitarians exemplify supporters of the informalist thesis, arguing for a unified informal sphere that involves strong commitment to democracy. These views, which require the informal sphere to embody a shared cultural orientation, engender concern about what I am calling of the dilemma of democratic informal politics. ${ }^{27}$ The

conception), more concrete, tight connections between the informal and formal sphere should be possible to make.

${ }^{25}$ To take just one example of the empirical counterevidence, educational levels, which are tied closely to social status, are highly correlated with individual levels of political participation. See Berinsky and Lenz, "Education and Political Participation."

${ }^{26}$ Beyond these points about presupposing democratic informal politics as causally necessary, the formalist thesis is too hasty in dismissing informal politics as inherently valuable to democracy. Some democratic theories, such as many versions of deliberative democracy, suggest the informal status of citizens is part of democracy's aim. These views see eliminating socio-cultural marginalization and disintegration as aims intrinsic to democracy. Democracy, they believe, means making sure that things like gender, class, and race do not undermine individuals' equal social status. Because the concept of democracy is at issue, those that deny the informalist thesis must undermine conceptions of democracy that incorporate informalism. That places a burden of proof onto the proponent of the formalist thesis to argue against substantive conceptions of democracy, like certain sorts of deliberativism.

${ }^{27}$ While this democratic communitarian position is obviously supportive of the informalist thesis, informalism need not entail such a maximalist democratic theory. The informalist thesis is compatible with a variety of theories of democracy, both austere and demanding ones. Consider minimalism, which likens democracy to a market where self-interested, dull-witted citizens choose political products (candidates). A minimalist like Richard Posner's view depends on 
means to pursue communitarian reforms of informal life raise serious objections. These objections, which I spell out in what follows, threaten to drive us away from democratic informal politics and, given what I have argued, away from realizing democracy.

\section{A. The Demands of Democratic Informal Politics}

We can begin by surveying some demands these theorists impose on the informal sphere. Rousseau, when considering the informal sphere, calls for a "legislator" to hand down a religiously infused culture to undergird citizens' adherence to democratic law. ${ }^{28} \mathrm{He}$ insists on state supervision of culture to maintain civic virtue, such as trying to keep the theater out of Geneva, his adopted home. ${ }^{29}$ In addition to suggesting that the state's geographical size be kept small, he thinks its way of life must be unified, solidary, and patriotic.

Benjamin Barber, who criticizes Rousseau despite being influenced by him, is also attracted to strong informal unity. Citizens, Barber says, ought to be "neighbors" who share a "common consciousness" - not strangers. Moreover, he laments that "dissent is a signal that community itself may be in jeopardy, while the presence of majorities and

accepting the informalist thesis, insofar as informal life is instrumentally important to the functioning of formal institutions. The people, he says, despite their political ignorance, are a "repository of common sense," preventing experts from implementing pie-in-the-sky proposals. See Posner, Law, Pragmatism, and Democracy, 168. Posner even suggests that a non-selfinterested, engaged populace is disastrous for democracy. See his Law, Pragmatism, and Democracy, 192-93. He thinks that given certain purported facts about human nature, democracy's political culture must be apathetic. Posner's implicit acceptance of the informalist thesis puts him in the company of those he is otherwise deeply opposed to in democratic theory like the democratic communitarians. Rousseau and Richard Posner make for strange bedfellows, but the informalist thesis, while compatible with and implicitly accepted by many views, is far from trivial. Accepting it forces theorists to confront the problem of democracy's scope without restricting their focus to formal political institutions. Even a minimalist who implicitly accepts the informalist thesis like Posner will need to answer the worries about democratic informal politics posed in this section.

${ }^{28}$ Rousseau, The Social Contract, 84-88.

${ }^{29}$ Rousseau, Politics and the Arts. 
minorities is a symbol of the disintegration of community altogether." ${ }^{30}$ While Barber accepts some conflict and disagreement, these statements raise worries about demanding too much social unity.

David Miller also has a strongly unitary view of democracy. He thinks it depends upon a national community with a shared "public culture," meaning "a set of understandings about how a group of people is to conduct its life together."31 This shared understanding includes political principles, social norms, and cultural ideals related to language and, most controversially, religion. Miller's public culture is not something monolithic that blocks out minority cultures or homogenizes a society, though; it can grow and change. Miller thinks the development of public cultures will be very nationspecific. While understandable, this approach leaves things vague. It raises concerns about whether his approach will be overly relativistic. ${ }^{32}$ His proposals for nationalistic civic education and other "nation-building" endeavors are also hard to evaluate without a concrete sense about how they would be pursued. ${ }^{33}$

Democratic communitarians believe democracy requires at least some substantive unity in the informal sphere; all citizens must have allegiance to the culture's democratic form of life. Everyday life should instrumentally support democracy, or even intrinsically realize democratic values. Such unity is particular to a society; it offers a value orientation around which the community can cohere and identify. Communitarians are so demanding because they believe democracy requires serious economic redistribution,

\footnotetext{
${ }^{30}$ Barber, Strong Democracy, 310.

${ }^{31}$ Miller, On Nationality, 26.

${ }^{32}$ His claim that "societies acquire the forms of government that suit them best," while meant to be anti-imperialist, has problematic relativist resonance, for example. Miller, On Nationality, 177. For a similar argument with such implications, see Walzer, "The Moral Standing of States."

${ }^{33}$ Miller, On Nationality, 178.
} 
which resultantly requires great commitment. Ties of mutual affection that only members of a common culture can develop enable such sacrifices, they believe.

Communitarian theorists' suggestions for developing and maintaining informal unity are worrisome, though. Rousseau suggests censors are an important way to express the community's judgment of components of cultural life. In Barber, we find unrealistic goals for citizen participation and unanimity in decision-making, eliciting worries about paralysis and de-facto conservatism. His insistence on "common consciousness" and strong communal solidarity also threatens to improperly exclude social "outsiders" and crowd out cosmopolitan views. ${ }^{34}$ Miller's nationalism, while expressed as inclusive, is vague enough to prompt similar worries about marginalization. If pursuing democratic informal politics engenders such problems, one might wish to return to formalism, even if doing so means falling short of democratically legitimate political decision-making. ${ }^{35}$

\section{B. Problems with Democratic Communitarian Demands on the Informal Sphere}

Worries about such views are not over unified communities themselves—if such things luckily emerge and flourish, few would object. Rather, the means democratic

\footnotetext{
${ }^{34}$ Barber thinks that participation, as well as other reforms, will move us toward democratic community, but it's hard to see how his proposed solutions fit the problem as he describes it. ${ }^{35}$ See, for example, Barry, Culture and Equality. Barry attacks multicultural theories of the informal sphere. Such multiculturalist views oppose Rousseau, Barber, and Miller's hope for unified communities. Nonetheless, multiculturalism's use of the state to recognize and promote multiple communities' values prompts objections similar to those made against communitarians (who hope to form and promote the entire society's shared values). The worry about democratic communitarians is that they will oppress or exclude minority positions. The worry about multiculturalists is that attempts to recognize and value minority viewpoints will oppress individuals who wish to dissent from such minority views (whether from inside or outside of those minority groups). Barry worries such dissent and critique is incompatible with multiculturalism, which wants broad affirmation and recognition of a plurality of cultures. To be clear, these objections to both multiculturalism and communitarianism are not against substantive values in public discourse, but to substantive values being given a privileged place simply because particular communities adhere to them. I do not take a position on multiculturalist views of democracy here; my only point is that these views elicit the worries about democratic informal politics that I address in this section.
} 
communitarians depend upon to engender unity are the main trouble. ${ }^{36}$ Objections to substantive, communitarian democratic informal politics can take two paths: practical and moral. Practically, unified informal politics seem unlikely to emerge in modern contexts. Morally, imposing stable democratic informal politics through state coercion seems likely to be ethically problematic and possibly exclusionary.

These issues place democrats in a dilemmatic bind. Democratic ideals demand certain forms of informal politics. But achieving and sustaining democratic communitarian informal politics appears immoral or even impossible. It seems democrats must either be unrealistic and oppressive or fail to realize democracy. After laying out these concerns, I will sketch an alternative approach to democratic informal politics, which avoids democratic communitarianism's problems.

The practical worries are very serious. Many philosophers and social theorists observe that modern informal spheres lack unity, coherence, or stable content. ${ }^{37}$ Without overthrowing the modern order for the sake of secure communitarian utopia, the informal sphere's instability appears a real obstacle. If one takes a communitarian approach, then liberal rights, creative economic destruction, technological change, and other components

\footnotetext{
${ }^{36}$ There may be even more fundamental objections to communitarianism: perhaps implementing the view inherently positions minority groups as less politically free and equal than those within majority communities, as an anonymous reviewer has suggested to me. There are likely other objections to the view, as well. For the purposes of my argument, I focus on objections to the means for developing the kind of informal sphere that democratic communitarianism recommends, since these objections are sufficient for generating the dilemma to which I respond. I focus on the objections that I do, because I view them as the source of many people's concerns about democratic informal politics.

${ }^{37}$ Consider John Rawls and Jürgen Habermas's views. In Political Liberalism, Rawls argues that reason operating under free institutions will not alight on any shared conception of the good. $\mathrm{He}$ seeks something much more minimal than communitarian unity. Habermas, discussing how the informal sphere resists organization, calls it "wild" and "anarchic." Habermas, Between Facts and Norms, 307-8. To be clear, he ultimately thinks that things can be done (such as encouraging independent media) to shape the public sphere in ways that will be friendly to democracy, but he is also very skeptical of democratic communitarianism.
} 
of modern life seem destined to undermine a democratic informal sphere. Even if these hurdles demonstrate that modern social systems should be jettisoned or reformed, it's implausible that we can eliminate all such disruptive forces for the sake of democratic communitarianism.

Further, the means to produce and support this informal political project may be lacking. People's beliefs and attitudes, their conscious and unconscious behaviors and tendencies, and other mysterious parts of practical life largely determine the informal sphere's character. The informal sphere seems not just unstable, but out of our control. Even if we somehow stabilized it, we'd be unlikely to achieve the unity communitarians require. Nor can we depend on Rousseau's legislator to appear and do it for us.

Even if these practical concerns can be overcome, moral difficulties remain. The use of legal coercion to impose such informal politics, even for democracy's sake, may prove oppressive or exclusionary.

It is hard to see how communitarians can avoid problematic legal coercion or running afoul of individual rights. Modest proposals for more political participation and national-identity fostering curricula appear inadequate for achieving the view's goals. David Miller, for instance, speaks admiringly of late $19^{\text {th }}$ century French modernization policies that fostered nationalism through compulsory education and military service. ${ }^{38}$ If that is what France needed, it is hard to see how less invasive policies will succeed today. This approach threatens to undermine basic rights and liberties. ${ }^{39}$ The view faces a head-

\footnotetext{
${ }^{38}$ Miller, On Nationality, 143. Miller calls the policies “over-strenuous," but their logic sound.

${ }^{39}$ One might worry that my claim about democratic informal politics proves too much. If informal politics can't be legitimately maintained, what about the formal political patterns necessary for democracy? My worry involves the difficulty of maintaining unified informal
} 
on collision with freedom of expression, religion, association, conscience, and other significant values. ${ }^{40}$

There are also moral concerns about democratic informal politics becoming exclusionary. The majority culture might dominate a unified informal sphere, or otherwise exclude reasonable citizens. Such hegemonic cultural patterns seem to be what democratic communitarians must rely on in the informal sphere. A society might try to legally preserve these patterns through education or regulation of cultural production, hoping to steer informal politics toward what the majority culture prefers. For many reasons, most reject excluding social groups through state supported cultural hegemony. ${ }^{41}$ If these worries about the legitimacy of fostering democratic informal politics are correct, the democratic cure for the informal sphere may be worse than the disease.

\section{Resolving Democracy's Dilemma through Proceduralism}

Given such arguments, we need a way to pursue democratic informal politics that [1] realizes democracy's values (the Democratic Requirement), [2] can be developed through realistic mechanisms (the Practical Possibility Requirement), and [3] is not exclusionary or oppressive (the Permissibility Requirement). If a version of democratic informal politics meets these requirements, we can avoid our apparent dilemma.

\section{A. Substantive and Procedural Approaches to Democratic Informal Politics}

patterns in particular, however. I assume democratic law can be legitimate and that objections to communitarian law could not be raised to formal patterns protecting political rights, for example.

${ }^{40}$ Barry expresses this objection in Culture and Equality. By trying to make individuals in society into neighbors, these proposals also conflict with what Habermas calls our right to "remain strangers." Habermas, Between Facts and Norms, 308.

${ }^{41}$ Political liberals like Rawls will worry about the legitimacy of any law based on such a comprehensive doctrine; it will fail to allow for mutual recognition and reciprocity between citizens on their view. Others will voice concerns about disintegrating members of minority cultures from the political process and undermining their citizenship rights. 
As we have seen, democratic communitarianism is ill suited to this project. That view pursues what I will call substantive democratic informal politics (SDIP). This approach demands that individuals in a society recognize the authority of the same informal normative structures. It requires them to identify with specific social norms and practices, as well as identifying with each other, ultimately forming a culturally integrated community.

For any particular normative structure in the informal sphere, SDIP asks whether it fits into society's shared culture in a way consistent with realizing democracy. Stronger versions of SDIP, like Rousseau's perhaps, demand that each normative structure help to produce democracy as understood by the unified community's culture. Other sorts of SDIP restrict their demands to a core set of informal normative structures (Miller's "public culture"). In its stronger and weaker variant, SDIP cannot avoid the dilemma of democratic informal politics, as we have seen.

In lieu of SDIP, the best candidate for meeting the three requirements is what I call, following Albrecht Wellmer, procedural democratic informal politics (PDIP). ${ }^{42}$ He explains, "We might, then, elucidate the term 'procedural' as follows: it means a way of dealing with dissent or conflict, in which orientation by the normative conditions of

\footnotetext{
${ }^{42}$ To forestall confusion, I should note that my use of the term procedural is not entirely parallel with the usage commonly found in political philosophy. Often, the idea of proceduralism is that a properly constituted democratic process is what matters for legitimacy, regardless of the outcomes of that process. When I use proceduralism, I mean to suggest that a type of informal politics counts as democratic by virtue of being compatible or consistent with a particular conception of the democratic process. In this respect, my usage of the term is closer to the proceduralism found in Habermas's Between Facts and Norms, which also sets substantive constraints on the informal sphere as a condition of democratic discourse. That means, then, that it is not an implication of my view that outcomes of democratic procedures do not matter. My use of the term "procedural" contrasts with a substantive approach to informal politics that evaluates elements of the informal sphere according to whether they fit into a particular, unified form of life. I thank James Bohman for pressing me to clarify this terminology.
} 
democratic discourse defines — not the only, but— the only ultimately obliging standard of judgment. ${ }^{, 43}$ PDIP identifies constraints on the informal sphere that are necessary to realize the democratic process, rather than requiring particular normative structures. To judge informal normative structures' adequacy, we ask if they can coexist with realized procedures of democracy in the formal and informal spheres.

Informal normative structures cannot be inconsistent with political freedom and equality on this view: they cannot causally undermine it and cannot inherently constitute political inequality or lack of freedom. How those committed to democracy should interpret political freedom and inequality in PDIP depends, of course, on what theory of democracy is best. ${ }^{44} \mathrm{~A}$ number of non-communitarian views of democracy can adopt versions of PDIP, though, such as minimalism, pluralism, and deliberativism.

For PDIP, unlike SDIP, the substantive content of the democratic informal sphere is left significantly open; communitarian unity and shared identification with particularistic informal normative structures is unnecessary. Instead, the shifting nature and contestability of normative structures in the informal sphere is assumed, albeit within constraints. ${ }^{45}$ Different individuals may act in accordance with different possible informal normative structures, so long as they are compatible with a democratic political process.

\footnotetext{
${ }^{43}$ Wellmer, "Conditions of a Democratic Culture," 51.

${ }^{44}$ In contrast to my more general approach, Wellmer only relies on Rawls, Habermas, and Walzer to spell out what democratic procedures and norms ought to look like. For both of us, though, informal social reconciliation is always incomplete; in modern societies, there is always some remainder of disunity.

${ }^{45}$ In contrast to the communitarian views I am discussing here, I do not take theories that depend on a "shared sense of justice" to be subject to these objections to cultural unity. I have in mind Forst's discussion in The Right to Justification or Rawls's even less demanding "overlapping consensus" in Political Liberalism. Such a "shared sense" is not a communitarian value orientation, but a commitment to universalistic rights to justification that distinguish the reasons relevant in political justification. These views permit significant disagreement and contestation. Views that advert to minimal unity over the form of political justification can avoid the problems faced by more expansive, particularistic views.
} 
PDIP requires that normative structures in the informal sphere, in conjunction with those in the formal sphere, deal with disunity and fragmentation in a way consistent with democratic values. That means various forms of life may co-exist and hold varying degrees of sway within a society, so long as they can coexist with a realized democratic process. When PDIP is realized in a society, there may be differing childrearing practices, varying understandings of appropriate speech, or diverse ways that non-state institutions like places of worship and social clubs are structured. These norms, practices, and understandings can be non-unitary, so long as they can coexist with normatively legitimate democratic procedures.

SDIP judges the democratic qualities of informal normative structures according to a thick, particularistic conception of democracy. Its standards are analogous to those that are meant for evaluating choreographed dancers. Dancers' movements, like relevant informal normative structures, are supposed to fit together coherently. This approach suggests that the informal sphere, like dancers' movements in a ballet, should exhibit unity or elements of design.

PDIP's standards are more like those for judging whether participants in a dance party are moving in ways appropriate to making the party successful. Dancers must respect constraints (i.e. not stepping on others' feet), but their movements needn't be in unison. People may dance with or without a partner, take breaks, and dance in different styles. A great dance party permits deviation and variation. There are some shared structures: the sound system and dance space, which roughly correspond to democracy's shared political institutions and processes. Like democracy, we could debate which conception of dance parties should guide our understanding of the constraints on 
participants in this practice. The sense in which conceptions of dance parties are analogous to PDIP, is in eschewing demands for unified movement. Informal normative structures in PDIP, like dancers' movements at a party, cannot be any which way, but can still take various disjunctive forms.

\section{B. Strong and Weak Substantive Democratic Informal Politics}

SDIP and PDIP's demands can be contrasted more concretely. SDIP's strongest form calls for widespread cultural unity for democracy's sake. The idea is that, by sharing many practices and values, people will share a national identity and accept the costs of taking part in a democratic process together. For instance, wealth redistribution, for the sake of preserving democratic social relationships, will be easier to accept. Without shared cultural commitments, the thought goes, people will reject such policies.

At its wildest extreme, this view demands identification with a set of informal normative structures constituting "cultural Britishness" or the ethos of whatever nation is at issue. In the British case, David Miller mentions love of the countryside and tea drinking (describing a cultural unity he does not endorse as politically requisite) ${ }^{46}$ The view requires the state to establish a particular religion, or even a common atheism. Education policy reinforces particular cultural commitments and immigration policy judges which entrants could best adopt this common culture. For obvious reasons, many find this view unacceptable. ${ }^{47}$

SDIP comes in weaker flavors, however. David Miller, for instance, endorses all the methods for developing the strongest sort of SDIP, but restricts shared ethos to a core

\footnotetext{
${ }^{46}$ Miller, On Nationality, 172.

${ }^{47}$ Such strong SDIP may be defended in Scruton, "In Defence of the Nation." Rousseau may have tendencies in this direction, as well, although this interpretive point is somewhat disputed.
} 
"public culture." He sees established religion as sometimes legitimate, insofar as society's public culture centers on a particular faith. Similarly, institutional policies about education and immigration, as well as informal symbols (like shared national flags), can be used to encourage collective identity. Miller is careful to note that transformative factors like immigration can shape and alter national identity to some extent. His sort of democratic informal politics need not be wholly static, so long as it remains unified.

Weak SDIP is superior to strong variants. It allows cultural pluralism if it fits with a core public identity. For instance, weak SDIP permits particular, divergent forms of life. What Miller calls "private" cultures may be austere or boisterous, religious or secular, trusting of others or skeptical of them. Weak SDIP just demands that adherents to varied ways of life share a core set of informal normative structures. ${ }^{48}$ Miller allows variation in how extensively shared informal normative structures must be. He says it must be broader than allegiance to common institutions or legal structures like a constitution. ${ }^{49}$ Instead, he suggests shared religion, traditions, common political understandings, and social norms can ground a thicker, particular identity.

While more limited than strong SDIP, Miller still requires conformity to a particular identity and set of informal normative structures. One counts as a social equal qua participant in British public culture, say. Further, it is unclear from Miller's account how political struggles over SDIP's content and scope should be adjudicated. There is no obvious criterion of correctness for such debates. Miller seems to view it like a

\footnotetext{
${ }^{48}$ Staying with the dance analogy, weak SDIP's requirements are analogous to those of a choreographed dance where dancers may occasionally improvise.

${ }^{49}$ Resultantly, Miller rejects Habermas's constitutional patriotism.
} 
competition, where emergent victors count as "authentic." ${ }^{.50}$ If forming national character constitutes such a power struggle, it is doubtful it can be fair, especially given preexisting imbalances in any given society. As the last section's arguments indicated, it is also hard to see how SDIP can develop in modern contexts, particularly without morally problematic coercion.

\section{The Advantages of Procedural Democratic Informal Politics}

PDIP can avoid these problems. Its concrete demands will, unlike SDIP, not presuppose a shared identity or set of informal normative structures. Instead, whatever informal normative structures hold sway must be consistent with democratic processes of decisionmaking, rather than some particular society-wide informal normative order. One begins one's democratic evaluation of the informal sphere with just a concept of democracy in mind, not a concrete, substantial cultural constellation. Some democratic theories, like minimalism, emphasize the formal sphere as the democratic process's location. Others include the informal sphere as part of the democratic process. For some deliberative democrats, deliberation in the informal public sphere is crucial to decision-making, for instance. Different democratic conceptions offer different verdicts about what sort of informal politics are needed, but each must make such judgments about it, I have argued. In judging education or immigration policy, for instance, PDIP asks if the resultant informal normative structures fit with the democratic process prescribed by the chosen democratic theory.

Suppose, arguendo, we take minimalism, a view compatible with PDIP, as the correct theory of democracy. Democracy, on this view, protects basic individual rights

\footnotetext{
${ }^{50}$ Miller, On Nationality, 40.
} 
and allows citizens to choose elites to rule over them. Democratic processes consist in citizens choosing who runs the formal institutions of government. Those elected must refrain from violating citizens' rights while governing.

Richard Posner's minimalism entails some basic informal political prerequisites. For one, citizens must be capable of pursuing their self-interest. ${ }^{51}$ This capacity lets them vote out politicians that support policies that harm them. Otherwise, society's informal political orientation ought to be disengaged, on this view. Informal norms and customs must discourage citizens from interfering with elected elites' decisions. ${ }^{52}$ Political engagement undermines what minimalists see as their view's appeal: protecting citizens' rights and interests without placing heavy demands on them.

Minimalism is, of course, highly controversial. Rather than endorsing it, I describe it merely to demonstrate how PDIP—with which minimalism fits—can avoid SDIP's problems. Take the following case: imagine that immigration greatly alters which particular, substantive informal normative structures hold sway in a society. Minimalist PDIP, by contrast to democratic communitarianism's SDIP, can accept this change. ${ }^{53}$ New citizens may introduce artistic traditions, religious practices, or political understandings. Suppose that entrants have a hippie ethos, while current citizens are more puritan and stern. The informal normative structures the hippies introduce are more approving of and conducive to freedom of expression (free love, valorization of nature,

\footnotetext{
${ }^{51}$ Posner, Law, Pragmatism, and Democracy, 168.

${ }_{52}^{52}$ Posner, Law, Pragmatism, and Democracy, 192-93.

${ }^{53}$ Even a paradigmatic supporter of weak SDIP, David Miller, explicitly defends immigration restrictions to bolster a particularistic national culture. Without opposing all cultural change, he still aims to minimize it. See Miller, "Immigration: The Case for Limits," 199-201.
} 
etc.). The population they join adheres to informal normative structures that maximize deliberative rationality (they promote serious normative discussion, say).

From minimalism's perspective, it is indifferent which informal normative structures take hold. Society might even become close to evenly divided if some puritans adopt hippie norms and understandings. This result is compatible with providing appropriate background for choosing elites to rule without violating individual rights. ${ }^{54}$ If people are generally commonsensical and willing to let elected politicians lead, society can realize minimalist democratic informal politics. PDIP, then, can provide much more free reign to the informal sphere than SDIP.

While I use Posner's minimalism as an example — because of its simplicity— many sorts of PDIP are possible, depending on one's conception of democracy. Differing conceptions set different constraints on informal life, based on their understanding of what democratic decision-making process requires. Like minimalist PDIP, though, various other versions of PDIP allow play and variation within their constraints. While some of these proceduralist views may fail, based upon my arguments so far I contend some versions of PDIP have hope of succeeding, in contrast to SDIP.

\section{Avoiding the Dilemma through Procedural Democratic Informal Politics}

PDIP can achieve the three requirements for avoiding the dilemma of democratic informal politics. It straightforwardly meets the democratic requirement. It is also

\footnotetext{
${ }^{54}$ Minimalism is a restrained view, so it is unsurprising it accepts these informal variations so sanguinely. Even a more ambitious view like participatory deliberative democracy seems able to accept the various informal shifts in the example, though. It requires that participation doesn't decline so much that deliberation becomes impossible. Also, relations between individuals from different groups can't degenerate into disrespect and misrecognition. Yet nothing about these informal variations necessitates such degeneration. Varying informal orders seem capable of serving as the background for the process of participatory deliberative democracy.
} 
plausible to think it can respect the practical possibility requirement. Given the empirical contingency involved, guarantees of success in democratizing the informal sphere will not be forthcoming. Crucially, though, PDIP's realistic possibility is not in serious doubt, in contrast to SDIP, which faces much greater barriers. Lastly, given the means available for developing PDIP, concerns about oppression and exclusion will be lessened; PDIP can meet the permissibility requirement.

In a way, PDIP's meeting the democratic requirement is definitional. For informal politics to be procedurally democratic is for background social conditions to be compatible with a democratic process's realization. That doesn't mean citizens constantly judge themselves through a democratic lens. We must only respond when informal normative structures interfere with realizing the democracy. At that point, democratic standards become a concern for informal sphere actors. ${ }^{55}$

Moreover, PDIP need not deny, or even lament, modernity's unstable, shifting character. ${ }^{56}$ That it need not do so allows it to avoid concerns about stability suggested by the practical possibility requirement. PDIP does not demand instability's disappearance, only its management in a way friendly to democracy. If, for example, groups are informally stigmatized and excluded from political power, PDIP demands reform of the informal sphere. Means to combat informal stigma are various. Rather than advocating censorship, when popular culture supports stigma, the best response may be protests

\footnotetext{
${ }^{55}$ I do not claim that democracy is an ultimate authoritative standard in such matters. Instead, I claim that to make an informal sphere democratic, actors would need to treat democracy as having such authority.

${ }^{56}$ There might be other reasons to find this instability problematic, orthogonal to one's acceptance of the desirability of democratic informal politics.
} 
meant to get the creators of such stigmatizing culture to rethink their practices. ${ }^{57}$ In other cases, where marginalized groups' voices are ignored in public discourse, structural reforms to promote their equal social status, like redistributive taxation, may be crucial. Informal normative structures that do not affect equal citizenship are irrelevant; their emergence or disappearance is not democracy's concern. Empirically, that may require widespread responsiveness to democratic values or it may be more minimal. ${ }^{58}$ All I claim is that democratic concerns transcend the formal political sphere. The hope is that the informal structures that must be responsive to democratic values will not be too extensive. PDIP focuses on contending with components of informal life that are conditions for democracy, insofar as they matter for democratic procedures.

These scaled-back aims make the goal of adequate democratic informal politics look more feasible than with SDIP. The required influence over the informal sphere will be less expansive than democratic communitarianism suggested. While luck will, of course, be needed, human beings are not entirely in the dark about how cultural reproduction works. J. S. Mill emphasizes the possibility of social learning. ${ }^{59}$ The shaping force of education also provides hope for proponents of democratizing change. ${ }^{60}$ Many

\footnotetext{
${ }^{57}$ One can look at recent backlashes against comedians' use of rape jokes, which many argue trivialize and even reinforce rape culture. In this case, it seems likely that attempts to censor comedians would be, at best, counterproductive. Although debates surrounding this issue continue, these informal protests have prompted a great deal of helpful soul-searching and dialogue in that profession.

${ }^{58}$ The scope of informal politics significantly depends on the conception of democracy at issue. ${ }^{59}$ See John Stuart Mill's insightful treatment of this issue at the outset of "Considerations on Representative Government."

${ }^{60}$ As Amy Gutmann says, "We have [...] considerable evidence that democratic virtue can be taught in many ways - by teaching male and female, Protestant and Catholic, black and white students together from an early age in the same classrooms; by bringing all educable children up to a high minimum standard of learning; by respecting religious and ethnic differences; by teaching American history not just as a series of elections, laws, treaties, and battles, but as lessons in the practice (sometimes successful, sometimes not) of political virtue, lessons that
} 
also view participation in private and semi-private civic associations and relationships as a means of shaping the informal sphere for democratic ends. ${ }^{61}$ Social movements are crucial, as well. Through protest, they can highlight informal sphere problems and advocate solutions. Social systems like law and non-discriminatory markets also have indirect, yet crucial (maybe decisive) roles to play in providing amenable conditions for democracy. Social scientific research, pursued with reference to particular conceptions of democracy, must fill in the details of any of these mechanisms, of course. Nonetheless, they offer numerous means to make the informal sphere more responsive to democratic values.

Even if we can causally accomplish this task, we still might worry about its permissibility. That the procedural view does not aim to unify the informal sphere offers hope that it can avoid oppression and exclusion.

By virtue of increasing responsiveness to democratic values, PDIP's changes should remove oppression, not impose it. The means through which I have suggested that informal politics can be improved offer further evidence that shaping the informal sphere doesn't necessitate oppressive policies. ${ }^{62}$ Education, civil associations, social movements,

require students to develop and to exercise intellectually disciplined judgment." Gutmann, Democratic Education, 63.

${ }^{61}$ Jensen, Liberal Democracy and Civil Society, provides a good overview of some of these approaches.

${ }^{62}$ A democratic communitarian might object that some of the defenses I offer for PDIP can also support SDIP. Admittedly, democratic communitarians can and do offer such defenses, pointing to the various means I propose for shaping informal politics; they claim SDIP can avoid problematic moral consequences. My response to this point is offered in the paper's earlier section where I outline how communitarianism generates concerns about democratic informal politics. To reiterate, SDIP can appeal to the same means for shaping informal politics as PDIP, but given the strong demands of SDIP, democratic communitarians' hopes of successfully relying on these means (rather than more oppressive ones) is implausible. Moreover, being committed to democratic values is not enough for communitarians to avoid oppression or exclusion, given that their conceptions of democracy are particularistic and overly unitary. 
and other systems can all both promote and lessen oppression. These proposals need not threaten to be more oppressive just because they advance PDIP. Caution must always be exercised and advocates of democracy must spell out how these means can support PDIP, particularly with respect to individual cases. The same points can be made about pursuing justice in formal politics, however.

PDIP aims to counter exercises of liberty and rights that undermine democratic values, though. For instance, this view discourages representations of social groups as unworthy of political inclusion. But that is not to say that the view demands that such representations be banned; freedom of speech is still crucial.

For example, take the use of the word "illegal" to marginalize, exclude, and devalue the humanity and labor of nonwhite racial communities in the United States - the slur often focuses on undocumented immigrants, but is sometimes applied more widely. ${ }^{63}$ Someone who holds the formalist thesis will not see a democratic problem here. Freedom of speech must be protected, so such language, while offensive, must be allowed. Furthermore, the formalist will reject any normative expectation that society ought to develop informal norms of speech supportive of democracy. While the proponent of the informalist thesis can agree about formally institutionalizing free speech, they will disagree with leaving open whether civil society's informal norms are democratic or not. From the standpoint of democracy, it is open to the informalist to object to the possible stigmatization consequent to the use of the word "illegal" (even if they have no desire to censor it). The best response to such slurs may be spontaneous, vocal social movements from the informal sphere itself. Such movements may persuade citizens of the

\footnotetext{
${ }^{63}$ Mendoza, “A 'Nation' of Immigrants,” 46-47.
} 
problematic nature of stigmatization, convincing them of the harm social disrespect does to marginalized groups. Challenging such language may reduce its predominance or acceptability in everyday life. Delicate cases where rights conflict with important goods are always difficult to approach, though — both for formalist and informalist approaches. Encouraging democratic theory to consider such informal political issues presents it with new challenges, but need not require it to become heavy handed and morally illegitimate.

Exclusion is supposed to be expressly avoided by proceduralizing democratic informal politics. PDIP need (and perhaps ought) not embody the majority culture qua majority culture. There is also no reason to ground its justification in a comprehensive doctrine; the values of democracy are all that are necessary. PDIP does not depend on deep solidarity centered on a particular communal value orientation, nor does it require the state to engender neighborly solidarity. It needn't be exclusionary, then.

\section{Conclusion}

The apparent dilemma that democracy faced as a result of needing certain sorts of informal politics presents less of a concern than it might have at first seemed. Accepting democratic demands on the informal sphere does not initiate an inexorable collision course with either practical impossibility or moral impermissibility, so long as we adopt a version of PDIP. Yet we should not be overconfident about democratic progress. My aim has been modest, although significant. In a Kantian or Rawlsian vein, the question at issue in contending with this dilemma is about what we can reasonably hope for. Because of the empirical, contingent nature of informal politics, there can be no definitive, general answer to worries about whether adequate democratic informal politics will emerge. It may never reach a sufficient level in most places, let alone a perfect one. As Wellmer 
puts it, the seemingly circular dilemma of informal politics "is an unavoidable practical

[problem] rather than an inherently vicious theoretical one. ${ }^{, 64}$ Through luck and effort, it is necessary to align the informal sphere and democratic values, if we truly care about democracy. What I have been trying to show is that we do not have philosophical reasons to give up on this project, given its role in democratic life. ${ }^{65}$

Department of Philosophy \& Religious Studies, Manchester University, Indiana SMMayer@manchester.edu

\section{References}

Allen, Danielle. Talking to Strangers. Chicago: University of Chicago, 2004.

Barber, Benjamin. Strong Democracy, $20^{\text {th }}$ anniversary ed. Berkeley: University of California Press, 2003.

Barry, Brian. Culture and Equality. Cambridge, Mass.: Harvard University Press, 2001. Berinsky, Adam, and Gabriel Lenz. "Education and Political Participation: Exploring the Causal Link," Political Behavior 33 (2011): 357-73.

Cohen, G. A. Rescuing Justice and Equality. Cambridge, Mass.: Harvard University Press, 2008.

Cohen, Joshua. "Privacy, Pluralism, and Democracy," in Philosophy, Politics, Democracy: Selected Essays, 303-325. Cambridge, Mass.: Harvard University Press, 2009.

Dawson, Michael. Black Visions. Chicago: University of Chicago Press, 2001.

Dryzek, John. Deliberative Democracy and Beyond. Oxford: Oxford University Press, 2000.

Forst, Rainer. The Right to Justification. New York: Columbia University Press, 2012.

Fraser, Nancy. "Rethinking the Public Sphere: A Contribution to the Critique of Actually Existing Democracy," in Justice Interruptus, 69-98. New York: Routledge, 1997.

Fricker, Miranda. Epistemic Injustice. Oxford: Oxford University Press, 2009.

Gottschalk, Marie. Caught: The Prison State and the Lockdown of American Politics. Princeton: Princeton University Press, 2015.

Gutmann, Amy. Democratic Education. Princeton: Princeton University Press, 1999.

\footnotetext{
${ }^{64}$ Wellmer, "Conditions," 45.

${ }^{65}$ Thanks to Kyla Ebels-Duggan, Rainer Forst, Richard Kraut, Cristina Lafont, Charles Mills, Italia Patti, Titus Stahl, two anonymous reviewers, and audiences at the International Social Philosophy Conference at Northeastern University, the Critical Theory Roundtable at University of Toronto, and two workshops at Northwestern University for comments and discussion of earlier drafts.
} 
Habermas, Jürgen. Between Facts and Norms. Cambridge, Mass.: MIT Press, 1996. Honneth, Axel. Freedom's Right. New York: Columbia University Press, 2014. Jensen, Mark. Liberal Democracy and Civil Society. New York: Routledge, 2011.

Korsgaard, Christine. The Sources of Normativity. Cambridge: Cambridge University Press, 1996.

Lerman, Amy, and Vesla Weaver. Arresting Citizenship: The Democratic Consequences of American Crime Control. Chicago: University of Chicago Press, 2014.

Mendoza, Jose Jorge. “A 'Nation' of Immigrants," The Pluralist 5 (2010): 41-48.

Miklikowska, Marta, and Helena Hurme. "Democracy Begins at Home: Democratic Parenting and Adolescents' Support for Democratic Values," Political Psychology 8 (2011): 541-57.

Mill, John Stuart. "Considerations on Representative Government" in On Liberty and Other Essays, 203-467. Oxford: Oxford University Press, 1991.

Miller, David. On Nationality. Oxford: Oxford University Press, 1995.

Miller, David. "Immigration: The Case for Limits," in Contemporary Debates in Applied Ethics, ed. A. Cohen and C. Wellman, 193-206. Malden: Blackwell, 2005.

Okin, Susan Moller. Justice, Gender, and the Family. New York: Basic Books, 1989.

Pettit, Philip. On the People's Terms: A Republican Theory and Model of Democracy. Cambridge: Cambridge University Press, 2012.

Pincione, Guido, and Fernando Tesòn. Rational Choice and Democratic Deliberation: A Theory of Discourse Failure. Cambridge: Cambridge University Press, 2006.

Polanyi, Karl. The Great Transformation. Boston: Beacon Press, 2000.

Posner, Richard. Law, Pragmatism, and Democracy. Cambridge, Mass.: Harvard University Press, 2003.

Rawls, John. A Theory of Justice. Cambridge, Mass.: Harvard University Press, 1971.

Rawls, John. Political Liberalism, expanded ed. New York: Columbia University Press, 2005.

Rousseau, Jean-Jacques. Politics and the Arts: Letter to D'Alambert on the Theatre. Ithaca: Cornell Press, 1960.

Rousseau, Jean-Jacques. The Social Contract. New York: Penguin, 1968.

Rosenblum, Nancy. "Democratic Families: 'The Logic of Congruence' and Political Identity," Hofstra Law Review 32 (2003): 145-70.

Sanders, Lynn. "Against Deliberation," Political Theory 25 (1997): 347-76.

Scanlon, T. M. "The Difficulty of Tolerance," in The Difficulty of Tolerance, 187-201. Cambridge: Cambridge University Press, 2003.

Scruton, Roger. "In Defence of the Nation," in The Philosopher on Dover Beach: Essays, 299-328. Manchester: Carcanet, 1990.

Stanley, Jason. How Propaganda Works. Princeton: Princeton University Press, 2015.

Walzer, Michael. "The Moral Standing of States: A Response to Four Critics," Philosophy and Public Affairs 9 (1980): 209-29.

Wellmer, Albrecht. "Conditions of a Democratic Culture: Remarks on the LiberalCommunitarian Debate," in Endgames, 39-61. Cambridge, Mass.: MIT Press, 1998.

Young, Iris Marion. Justice and the Politics of Difference. Princeton: Princeton University Press, 1990.

Young, Iris Marion. Inclusion and Democracy. Oxford: Oxford University Press, 2000. 